\title{
HEALTH CAPITAL AND ITS RELATIONSHIP TO ECONOMIC GROWTH
}

Daniel Zarzycki

Department of Econometrics, University of Lodz

Maciej Malaczewski, Associate Professor, Ph.D. Department of Econometrics, University of Lodz

(iD) https://orcid.org/0000-0001-7798-2581

\begin{abstract}
The purpose of the article/hypothesis: The purpose of this paper is to attempt to justify the thesis that the health potential of human and society has an impact on economic well-being, contributing to the economic growth of countries, and thus their enrichment.

Methodology: In order to examine the significance and strength of the impact of health capital on productivity on a macroeconomic scale, an econometric model of economic growth was used and six estimations were made in which the impact of subsequent components of this capital was examined.

Results of the research: It turned out that 4 out of 6 introduced variables of health capital significantly influenced economic growth, and their direction is consistent with the economic theory. This implies necessity for further studies.
\end{abstract}

Keywords: economic growth, health indicators, health capital.

JEL Class: C21, I15, 047. 


\section{INTRODUCTION}

Health from the earliest times has been a matter of concern for man and society, and its lack is widely recognized as one of the main causes of life shortages and the inability to fully realize human potential. Still unexplored possibilities of man and his ability to influence and transform the environment in which he lives are the subject of many studies in which the value and significance of health potential is increasing more and more. The high level of this potential can co-decide on the development of individuals and societies on many levels, which is not without significance for economic and financial well-being on a micro- and macroeconomic scale. The growing awareness of the measurable benefits of investing in health capital, encourages economists and analysts to attempt to value human health and life. Such a trend has been observed for years, among others in the insurance industry or in the sector of health care services. Health ,valuation” often involves estimating the value of income that a person could get if he could work in full health, as well as focusing on estimating the costs incurred as a result of chronic diseases or civilization diseases. In both of these cases we can say about the increasing or decreasing ability to increase the well-being of individuals and economies, which can be reflected in the financial situation of households - on the one hand, as well as in the size of national income or GDP - on the other.

The purpose of this paper is to attempt to justify the thesis that the health potential of human and society has an impact on economic well-being, contributing to the economic growth of countries, and thus their enrichment. To this end, the importance of health considered in the context of economic capital was presented, indicating its most important areas and determining the determinants on which the size of the health potential of individuals and societies depends. After the theoretical part, the conclusions of the econometric study, in which individual components of health capital were introduced to the basic model of economic growth to examine the significance and strength of the impact of health capital on the rate of economic growth were presented.

According to the authors, a comprehensive approach to health analysis through the prism of its most important determinants should replace the current attempts to include in the models of economic growth only the indicator of average life expectancy or the mortality rate and theirs modifications. These indicators may not provide full information on the potential impact of health on economic growth. The contribution of this article to the literature is an indication that in econometric studies of the impact of health capital on economic growth a different approach is also possible. 


\section{HEALTH AS AN ECONOMIC CAPITAL}

The health of individuals and society, and the role of the state in its maintenance in terms of potential economic benefits is the subject of economic interest. In this sense, health may be perceived as a special kind of resource or capital conditioning the productivity of both individual enterprises and entire economies, which contributes to their growth at the national and global level [Marchewka 2000: 106-107].

The concept of „capital” seems to be extremely important in this perspective, which can be defined in many ways as a separate issue. In the classic approach proposed by Adam Smith, capital (in this approach - only physical capital), next to work and land, is one of the basic factors of production [Marchewka 2000: 106-107]. A more general definition is provided by the Encyclopedia of Management, according to which capital is a type of resource for multiplying economic benefits in three different forms: cash resources, means of production and intangible resources [www1, access 20.05.2019].

In recent years, particular attention has been paid to the role of non-material production factors, which in the literature of the subject are referred to as human and social capital. The concept of the so-called „Living capital”, which is defined as ,capital contained and embodied in people, unlike land, buildings, machinery and other tangible assets" [Roszkowska 2013: 12]. It can therefore be said that the most valuable resources in enterprises and the economy also include human knowledge, skills and competences along with their health and the natural need to create and nurture social bonds. An example of such an approach can be the definition of the American economist Theodore Shultz, who defined human capital as: „the resource of knowledge, skills, health and vital energy contained in society. This resource is not given by the genetic characteristics of the population once and for all, but it can be increased through investments called investments in people: in people, in human capital, in human life" [Roszkowska 2013: 13].

Health, in addition to education and the ability to live in organized society, is therefore treated as a special resource that enables individuals a meaningful, creative and satisfying life and influencing their own biological heritage. The possibility of ,investment" or increasing the health potential by the individual and indirectly by governments is emphasized in some views of the health resource as „biological capital” or ,physiological capita” [Domaradzki 2013: 410].

Biological capital is defined as a set of relatively persistent psychophysical features important from the point of view of the effective adaptation of individuals to applicable system rules, which may appear as factors facilitating or even enabling success in specific areas of social life. Its main components include: strict health (no illness), physical and mental fitness, youth and beauty. The possibility 
of influencing the biological heritage understood in this way links more closely what is called health capital with the consumption of health goods such as: fitness services, plastic surgery, healthy food, instructors and dietitians' advice in the field of cosmetology or health promotion [Domaradzki 2013: 417]. Thus, it can be said that health in economic terms can also be a "commodity" that is purchased by consumers expressing demand for health services. This is conducive to the commercialization of the healthcare sector, which is confirmed by the trend of increasing spending on health by governments.

The author of the concept of physiological capital is the Nobel laureate, American economist Robert Fogel, who explained the increase in health and economic potential as a consequence of the progressing physiotechnological evolution [Fogel 2012: 112-113]. According to Fogel, in the last three centuries, man has managed to significantly take control of the surrounding environment. This impact, combined with technological progress, makes the environment undergo constant transformations, which are characterized by high dynamics, and consequently also lead to adaptive changes of the human body. According to the author of this concept, the average body size increased by about $50 \%$ and life expectancy by over $100 \%$, which led to a great improvement in the strength and abilities of the human body. According to the economist, the concept of physiological capital is a logical consequence of the theory of physiotechnological evolution and is associated with human life opportunities that change from generation to generation. The accumulation of this capital means an increase in the vital forces of the human body as a result of overcoming the problem of chronic malnutrition and overall improvement in living conditions, and is expressed in an increase in body weight, reduced susceptibility to disease, prolonged life, and increased physical and intellectual fitness. According to Fogel, this resource can be accumulated by influencing its two basic components: thermodynamic and physiological, which translates into economic growth and in this sense can be considered as an important element of government policy.

Health capital, being an economic category, creates the basis for examining and maintaining health in the category of financial expenditure incurred on a macro scale - by the state and micro - by numerous economic entities, mainly households. The cost of obtaining and maintaining health is estimated by many institutions related to the health sector, which include pharmaceutical, insurance, transport and environmental protection agencies, which, for example, value the costs of environmental degradation taking into account the increase in morbidity and premature deaths due to this reason.

Being valued, health as capital is also subject to the laws of supply and demand [Morris 2012: 20]. Demand for health is often perceived in an effective approach and is expressed as the actual desire and opportunity to purchase a specific good or medical service. On the other hand, the supply of health is 
understood as expenditure incurred for organizing production factors (staff, buildings, raw materials) in order to offer goods and services, i.e. health services that are in demand [Korporowicz 2011: 75]. As can be seen, health as capital may be subject to various economic analyzes, however, being a non-material and inherent resource in every human being, it cannot be the subject of trade, and thus cannot be analyzed using market mechanisms. In this context, the theory of health production is very important from the point of view of determining the demand and supply for this resource. Grossman pointed out the possibility of producing the good called health [Morris 2012: 25] claiming that health is a resource that produces ,healthy time" in which human being achieves optimal productivity. The capital in this approach is the initial stock of health which is depreciated and in which one should invest, and the production function itself depends on the unit's efficiency defined as the amount of health obtained from a given amount of expenditure on this resource. Production of health in terms of supply means the relationship between factors used in the production process (buildings, staff, equipment) and the result of this process (the number of services in the field of health protection and their quality). This approach allows you to measure factors and products in many ways and observe the various relationships between them. This is useful in determining the effectiveness of certain moves, such as: Is it more profitable to run a large or small hospital?; How much will the number of services provided in the facility increase assuming that an additional nurse will be employed? e.t.c. [Morris 2012: 23].

Thus, it can be said that health, being a non-material type of capital, is becoming increasingly important for economies, and awareness of its impact on the well-being of individuals and societies is the basis for emphasizing its distinctiveness in economic analyzes. For this reason, health capital is defined mainly as the potential for life and health, which depreciates with age and depletes upon death, in which investments can be made through health-promoting policies of governments and conscious choices. Poor health determined by chronic illness or mental health problems reduces the individual's productivity, potentially also reducing professional activity and the period of employment, which negatively affects the productivity of enterprises and economies on a macro scale. Important features of health capital include: it can be produced and can be increased through investment, has an impact on human well-being and productivity of the economy, can be considered in terms of demand and supply, is a rare good in relation to human expectations. 


\section{HEALTH CAPITAL DETERMINANTS}

The most commonly used indicators representing the health of the population include life expectancy, which among the many alternatives used is an indicator of variance least susceptible to changes in the set of explanatory variables considered significant in growth models. Researchers using average life expectancy in growth models include Barro and Sala-i-Martin [2004], Easterly and Levine [1997], Sachs and Warner [1997], Bhargava et al. [2001] and Bloom [2004]. The positive impact of this indicator on economic growth is noted by Arora [2001], who claims that over the past century, health improvement has not only been a side effect of growth, but has also been conducive to it by increasing long-term growth by around 30-40\% in industrialized countries. Cooray [2013] comes to different conclusions, which focuses on showing the diverse impact of health capital on economic growth in countries with different income levels. According to this author, each subsequent year of life of men causes an increase in the rate of economic growth by $0.05 \%$. In addition to the expected life expectancy of women and men, the set of variables reflecting population health included natural increase, government spending on health and adult survival rate.

A popular and quite often used indicator in studies of the impact of health on economic growth is the Adult Survival Rate. Bhargava et al. [2001] introduce an adult survival rate and fertility rate into the growth model, and the data is estimated on a sample of 73 countries over a 25 -year period. The estimation results are compared for data obtained from the Penn World Table (PWT) and World Database Indicators (WDI) in two approaches: the first assumes the exogenity of delayed GDP and the growth rate, in the second approach they are treated as endogenous variables. The models show a significant impact of the „Adult Survival Rate" (ASR) indicators for low-income countries. In the poorest countries, a $1 \%$ change in ASR is associated with an increase of around $0.05 \%$ in the rate of economic growth. Similarly, an increase in the ratio of investment outlays to GDP by $1 \%$ is associated with an increase in the growth rate of only $0.014 \%$.

The first attempts to construct synthetic measures relating to health can be seen in the works of Torrance [1976] and Holland [1985]. In his work, Torrence presented a synthetic development of fourteen health indexes based on the analyzed empirical studies of other authors in order to unify the concept, terminology and mathematical notification in the methodology of creating next indicators. In Holland's monoraph, however, practical methodological guidelines for the construction of indexes relating to economic methods of analyzing the benefits and values lost by patients can be found. To this end, the author identifies three methods for quantifying health change: the use of a subjective 
health scale in many aspects; willingness to consume or receive health care and to use the measure of the number of years of life corrected by its quality (QUALY).

From the point of view of health capital, it is extremely important to try to identify and explain the factors determining its formation. In the context of contemporary thinking about health, the basis for further reflection in this regard is the concept created by the Minister of Health of Canada - Marc Lalond in 1974, called the „fields of health" model [Sygit 2017: 28]. This model shows health determinants in a broader connection with the social context and divides them into four areas: lifestyle, environment, medical care and human biology.

According to the results published in the minister's report, medical services and health care determine the health potential of an individual to the least, as the impact fluctuates around $10 \%$. More important, because $15 \%$ impact is characterized by human biology, i.e. genetic factors on which a person has no real influence. The environmental impact of health has been estimated at $25 \%$. In this group of factors there are elements such as: employment conditions, housing conditions, income or cultural norms. The most important element determining health in 50\% turned out to be lifestyle, which included all human decisions, usually as repetitive habits and habits acquired in the course of life, stimulating health (e.g. regular physical exercises) or leading to its gradual degradation (e.g. smoking, inadequate diet, alcohol abuse). In view of the above results, the emphasis was primarily on the decisive role of the individual's responsibility for their own health.

The „health fields” model is useful from the perspective of the individual's health, but it is not sufficient from the point of view of the population's health, which is why it was decided to extend it. Such an attempt was made, among others in the „Investment for Canadians' health” strategy [Woynarowska 2013: 45], which lists the following factors on which public health depends:

- earnings and social status - considered to be the most important single factor affecting health, the higher the income and status, the better the health;

- social support networks - support from family and friends reduces the risk of many diseases and destructive behavior in the local community;

- education - its higher level increases the ability of people to manage their lives and control their health, and improves their chances of getting a job;

- employment and working conditions - unemployment increases the risk of health problems, especially depression and anxiety, and gradual social isolation;

- physical environment, which can be divided into: natural (the state of air, water, soil) and created by man (safety in the place of residence, workplace, in traffic);

- biology and genetic equipment - the individual's genetic potential, functions of individual body systems and their age; 
- health behaviors and ability to deal with stress - directly affect human health, but are dependent on social factors, as well as knowledge and skills to make the right choices;

- proper development in childhood - starting from the fetal period and in early childhood, is of fundamental importance for health and well-being in later life;

- health care - in an organized and directed form to protect and improve health and disease prevention;

- gender - other causes of loss of health due to gender are observed, e.g. men are mainly cardiovascular diseases, fatal accidents and cancer, while women are more at risk of developing depression or chronic diseases such as allergies;

- culture - all dominant cultural values constituting a risk factor for certain social groups (stigmatization or marginalization).

Similarly, the factors conditioning human health are viewed by WHO, which on the Health Knowledge Portal in addition to defining its essence, also gives determinants, which include: income and social status; education; physical environment; social support networks; genetics, healthcare and gender. It is worth noting that in this perspective, the lifestyle and ability to cope with stress have been classified as factors related to human genetic conditions, and the wider context of the impact of culture, social habits and traditions has been placed in the category of building social bonds.

Referring to the above analyzes, it can be said that today, the quality of health capital is largely determined by socio-economic factors and lifestyle. The latter emphasizes the importance of conscious human choices in accordance with ,your health in your hands", which should be focused on health-promoting activities. Among these behaviors, four basic groups can be distinguished:

- behaviors related mainly to physical health - care for the body and the immediate surroundings, physical activity, rational nutrition, hardening and sleep;

- behaviors related mainly to psychosocial health, i.e. using and giving social support as well as dealing with problems and stress;

- preventive behavior, i.e. self-examination of health, undergoing preventive examinations, safe behavior in everyday life (in traffic, work, etc.), which also includes sex life;

- elimination of risky behaviors, which include: smoking, alcohol consumption, abuse of prescribed drugs and the use of other psychoactive substances [Woynarowska 2013: 52]. 


\section{HEALTH CAPITAL AND ECONOMIC GROWTH - ECONOMETRIC MODEL AND ESTIMATION RESULTS}

Hypotheses about the potential impact of health on economic growth should be confirmed in empirical econometric studies. The parameters were estimated in the GRETL econometric package using the Classic Least Squares Method (KMNK). In order to verify the hypothesis about the significant impact of various components of health capital on economic growth, it was necessary to estimate the parameter for each component regardless of the other additional tested factors. Such action eliminated the potential impact of disturbances caused by subsequent indicators, which could lead to collinearity.

The data used for the model comes from the World Bank and the World Health Organization databases and include 6 variables related to specific dimensions of health capital for 208 countries. Most of the indicators were collected for the years 2000-2017, which was the adopted time horizon, but it was not possible for everyone to obtain average values based on a minimum of 18 observations, therefore, in each estimation we use as many observations as possible. Individual variables were introduced sequentially to the typical economic growth model (initial model), which - according to the assumptions of the theory of economic growth - took into account three main determinants:

- GDP per capita measuring the strength of economic convergence;

- Investment rate measuring the investment level;

- A variable related to human capital (usually illustrating the level of education).

The dependent variable was the economic growth rate of GDP per capita, while the variable representing human capital was the net enrollment rate determining the number of children actually enrolled in schools. The list of variables used in the model along with their characteristics is below in the Table 1.

Table 1. List of variables used in the econometric model

\begin{tabular}{|c|c|c|c|}
\hline Category & $\begin{array}{c}\text { The name of the variable } \\
\text { in the database }\end{array}$ & Description & $\begin{array}{l}\text { The name of the } \\
\text { variable in the model }\end{array}$ \\
\hline Economic growth & $\begin{array}{l}\text { GDP per capita growth } \\
\text { (annual \%) }\end{array}$ & $\begin{array}{l}\text { Economic growth rate of } \\
\text { GDP per capita in USD at } \\
\text { constant prices for } 2010\end{array}$ & m_wzrost \\
\hline $\begin{array}{c}\text { Economic } \\
\text { convergence }\end{array}$ & $\begin{array}{l}\text { GDP per capita } \\
\text { (2010 US\$) }\end{array}$ & $\begin{array}{l}\text { GDP per capita in USD at } \\
\text { constant prices for } 2010\end{array}$ & m_pkb \\
\hline Investment level & $\begin{array}{l}\text { Gross capital formation } \\
\text { (\% of GDP) }\end{array}$ & $\begin{array}{c}\text { The level of investment in } \\
\text { physical capital calculated as } \\
\text { a \% share in GDP }\end{array}$ & m_inwestycje \\
\hline $\begin{array}{l}\text { Investment in } \\
\text { Human capital }\end{array}$ & Net enrollment rate & $\begin{array}{c}\text { The net enrollment rate } \\
\text { determines the share of } \\
\text { school-age children actually } \\
\text { enrolled in schools }\end{array}$ & m_edukacja \\
\hline
\end{tabular}


Table 1. (cont.)

\begin{tabular}{|c|c|c|c|}
\hline Category & $\begin{array}{c}\text { The name of the variable } \\
\text { in the database }\end{array}$ & Description & $\begin{array}{c}\text { The name of the } \\
\text { variable in the model }\end{array}$ \\
\hline Healthcare & $\begin{array}{l}\text { Current expenditures on } \\
\text { health per capita }\end{array}$ & $\begin{array}{c}\text { Current expenditure on } \\
\text { health services per capita in } \\
\text { USD }\end{array}$ & sl_zdrowia \\
\hline Lifestyle & $\begin{array}{c}\text { Prevalence of obesity } \\
\text { among adults, } \mathrm{BMI} \geq 30\end{array}$ & $\begin{array}{l}\text { The obesity coefficient } \\
\text { determines the percentage of } \\
\text { population for which the } \\
\text { BMI (body mass index) } \\
\text { value exceeds } 30 \text { points }\end{array}$ & st_zycia \\
\hline $\begin{array}{c}\text { Physical } \\
\text { environment }\end{array}$ & $\begin{array}{l}\mathrm{CO}_{2} \text { emissions (metric } \\
\text { tons per capita) }\end{array}$ & $\begin{array}{c}\text { Carbon dioxide emissions } \\
\text { measured in tonnes per } \\
\text { capita }\end{array}$ & sr_fizyczne \\
\hline $\begin{array}{l}\text { Man-made social } \\
\text { environment }\end{array}$ & $\begin{array}{l}\text { Intentional homicides } \\
\text { (per } 100,000 \text { people) }\end{array}$ & $\begin{array}{l}\text { The premeditated homicide } \\
\text { rate determines the number } \\
\text { of killings inflicted as } \\
\text { a result of conflicts and } \\
\text { interpersonal violence } \\
\text { per } 100,000 \text { people }\end{array}$ & sr_spoleczne \\
\hline $\begin{array}{l}\text { Demographic } \\
\text { factors }\end{array}$ & $\begin{array}{l}\text { Age dependency ratio } \\
\text { (\% of working-age } \\
\text { population) }\end{array}$ & $\begin{array}{c}\text { The demographic } \\
\text { dependency ratio determines } \\
\text { the percentage of persons } \\
\text { under } 15 \text { years of age } \\
\text { or above } 64 \text { years of age } \\
\text { in relation to persons of } \\
\text { working age (15-64 years) }\end{array}$ & cz_demograficzne \\
\hline Economic factors & $\begin{array}{l}\text { Unemployment rate, total } \\
\text { (\% of total labor force) }\end{array}$ & $\begin{array}{l}\text { The unemployment rate } \\
\text { determining the percentage } \\
\text { of people of working age } \\
\text { unemployed and actively } \\
\text { looking for a job }\end{array}$ & cz_ekonomiczne \\
\hline
\end{tabular}

Source: own elaboration based on collected data.

Before proceeding to the estimation of selected variables of health capital, it was necessary to check the significance of the initial model into which further variables could be entered. To this end, the significance of all predictors was tested, the directions of the influence of explanatory variables on the explained theory were compared, and the normality and homoscedasticity of the random component were tested to obtain the correct values of statistics in the model and the most desirable estimators - the BLUE class.

In the next step, parameters of six models were estimated, which is presented and described below. In the estimation, the estimator resistant to heteroscedasticity of residues (,robust”) is used. Due to the occurrence of atypical observations, dummy variables for selected countries have been added in some estimates. The estimation results are presented in the Table 2. 
Table 2. Estimation results for the initial model extended by variables of health capital

\begin{tabular}{|c|c|c|c|c|c|c|c|}
\hline \multirow{2}{*}{ Estimation } & \multicolumn{7}{|c|}{ Dependent variable: m_wzrost } \\
\hline & $\mathbf{0}$ & $\mathbf{1}$ & 2 & 3 & 4 & 5 & 6 \\
\hline Benchmark model & \multicolumn{7}{|c|}{$\begin{array}{l}\text { Impact and significance of estimators } \\
\text { (level of significance at: } * * *<0.01, * *<0.05, *<0.1)\end{array}$} \\
\hline m_pkb & $\begin{array}{c}-4.0 \mathrm{e}-05 \\
* * *\end{array}$ & $\begin{array}{c}-7 \mathrm{e}-05 \\
* * *\end{array}$ & $\begin{array}{c}-4 \mathrm{e}-05 \\
* * *\end{array}$ & \begin{tabular}{|c|}
$-2.8 \mathrm{e}-05$ \\
$* * *$
\end{tabular} & $\begin{array}{c}-4.46 \mathrm{e}-05 \\
* * *\end{array}$ & $\begin{array}{c}-4.45 \mathrm{e}-05 \\
* * *\end{array}$ & $\begin{array}{c}-4.5 \mathrm{e}-05 \\
* * *\end{array}$ \\
\hline m_inwestycje & $\begin{array}{c}0.0838319 \\
* * *\end{array}$ & $\begin{array}{c}0.07456 \\
* * *\end{array}$ & $\begin{array}{c}0.08558 \\
* * *\end{array}$ & $\begin{array}{c}0.07338 \\
* * *\end{array}$ & $\begin{array}{c}0.08990 \\
* * *\end{array}$ & $\begin{array}{c}0.08346 \\
* * *\end{array}$ & $\begin{array}{c}0.0866 \\
* * *\end{array}$ \\
\hline m_edukacja & $\begin{array}{c}0.0144229 \\
* * *\end{array}$ & $\begin{array}{c}0.01807 \\
* * *\end{array}$ & $\begin{array}{c}0.03134 \\
* * *\end{array}$ & $\begin{array}{c}0.01981 \\
* * *\end{array}$ & $\begin{array}{c}0.01589 \\
* * *\end{array}$ & $\begin{array}{c}0.01537 \\
* * *\end{array}$ & $\begin{array}{c}0.0163 \\
* * *\end{array}$ \\
\hline Myanmar & $\begin{array}{c}6.21619 \\
* * *\end{array}$ & $\begin{array}{c}6.33371 \\
* * *\end{array}$ & $\begin{array}{c}5.66077 \\
* * *\end{array}$ & $\begin{array}{c}6.27711 \\
* * *\end{array}$ & $\begin{array}{c}6.03022 \\
* * *\end{array}$ & $\begin{array}{c}6.19220 \\
* * *\end{array}$ & $\begin{array}{c}6.0719 \\
* * *\end{array}$ \\
\hline Health capital & \multicolumn{7}{|c|}{$\begin{array}{l}\text { Impact and significance of estimators (level of significance at: } \\
\qquad * * *<0.01, * *<0.05, *<0.1)\end{array}$} \\
\hline sl_zdrowia & & $0.00032 *$ & & & & & \\
\hline st_zycia & & & $\begin{array}{c}-0.0682 \\
* * *\end{array}$ & & & & \\
\hline sr_fizyczne & & & & $-0.0697 * * *$ & & & \\
\hline sr_spoleczne & & & & & $-0.0241 * * *$ & & \\
\hline cz_demograficzne & & & & & & $-7.93 \mathrm{e}-05$ & \\
\hline cz_ekonomiczne & & & & & & & $-0,014157$ \\
\hline Ethiopia & & 4.70680 *** & & $4.68465 * * *$ & & & \\
\hline Guinea Equator. & & $4.41958^{* * * *}$ & & $4.27819^{* * *}$ & & & \\
\hline Cambodia & & $4.10926 * * *$ & & $4.08912 * * *$ & & & \\
\hline East Timor & & $4.21839 * * *$ & & $4.07339 * * *$ & & & \\
\hline R-square & 0.742170 & 0.80571 & 0.76871 & 0.805336 & 0.749305 & 0.745023 & 0.751051 \\
\hline JB. & 0.137392 & 0.51798 & 0.14459 & 0.677138 & 0.191532 & 0.128725 & 0.125214 \\
\hline Breusch-Pagan & 0.34556 & 0.51074 & 0.11472 & 0.869446 & 0.117832 & 0.140812 & 0.377789 \\
\hline $\mathrm{N}$ & 154 & 150 & 133 & 153 & 153 & 152 & 150 \\
\hline
\end{tabular}

Source: own calculations based on GRETL software.

Among the variables related to health potential, four parameter estimates turned out to be significant, including variables: sl_zdrowia, st_zycia, sr_fizyczne and sr_spoleczne. The insignificant predictors include cz_demograficzne and cz_ekonomiczne.

The parameter estimates obtained in the course of the conducted tests can be interpreted as follows:

- Increase in the percentage of population for which the BMI exceeds 30 points by 1 p.p. will cause the average economic growth rate to decrease by c.a. 0.068 p.p, respectively; 
- Pollution and degradation of the physical environment by excessive carbon dioxide emissions into the atmosphere negatively affects growth. The value of the estimator for the variable sr_fiz_1 informs that an increase in $\mathrm{CO} 2$ emissions by one tone per person will cause a decrease in the GDP growth rate per capita by c.a. 0.07 p.p.;

- A decrease in security in the immediate human environment, expressed by an increase in the number of premeditated homicides by a thousand, will translate into a decrease in the rate of economic growth by approx. 0.024 p.p.;

- An increase in expenditure on health care increases the rate of economic growth. Increasing expenditures for this purpose by one dollar per capita will increase the GDP growth rate by approx. 0.032 p.p.

In the course of the study, it turned out that 4 out of 6 introduced health capital variables turned out to significantly affect economic growth. It is worth noting that the selection of variables for the model was arbitrary, which means that there may be much more indicators related to the state of health reported regularly, including by WHO or World Bank, which may significantly contribute to the increase or decrease of the GDP per capita growth rate. The direction of impact and the value of the resulting parameter estimates appear to be consistent with economic theory.

According to the authors, these premises point to the need to continue research related to the impact of health capital on economic productivity, both on a micro and macroeconomic scale. An interesting idea might be to create an index for such capital that could aggregate the most representative variables for its individual areas. In addition, the development and creation of such an index could be an interesting alternative to indicators that are most popular in econometric studies, i.e. average life expectancy and adult survival rate.

\section{SUMMARY AND CONCLUSIONS}

Health, being a non-material type of capital, is becoming increasingly important for economies, and awareness of its impact on the financial and economic wellbeing of individuals and societies of individuals and societies is the basis for emphasizing its separateness in economic analyzes. Health capital is defined mainly as the potential for life and health, which with age depreciates and depletes upon death, in which investments can be made through health-promoting policies and conscious human choices. The important features of health capital include that: it can be produced and can be increased through investment, has an impact on human well-being and productivity of the economy, can be considered in terms of demand and supply, is a rare good in relation to human expectations. 
The starting point for determining the determinants of health capital is the concept of ,health fields" of the Canadian Minister of Health of the 1980s - M. Lalonde, who indicated that human health is affected by: lifestyle (in 50\%), environment (25\%), genes (15\%) and healthcare (10\%). Today, the ,health fields" model is being analyzed in the broader context of the health of societies. The determinants of health potential include: income and social status; education; physical and social environment (including social support networks), genetics, health care and demographic factors (including generational replacement and gender structure). The quality of capital, which is health, is largely determined by socioeconomic factors and lifestyle. The latter emphasizes the importance of conscious human choices in accordance with ,your health in your hands”, which should be focused on health-promoting activities.

In order to examine the significance and strength of the impact of health capital on productivity on a macroeconomic scale, an econometric model of economic growth was used and six estimations were made in which the impact of subsequent components of this capital was examined. Data for the model came from the WHO database and the World Bank for 208 countries from 2000-2017.

In the course of conducted research, it turned out that 4 out of 6 introduced variables of health capital significantly influenced economic growth, and their direction is consistent with the economic theory. These include: carbon dioxide emissions in tones per capita (physical), health care expenditure in dollars per capita (sl_zdrowia), the percentage of obese people (lifetime) and the coefficient determining the number of homicides inflicted as a result of conflicts and interpersonal violence per 100,000 people. Insignificant variables in the model were demographic load factor (demographic parts) and unemployment rate (economical parts).

There is no doubt that there may be much more indicators related to health capital regularly reported, including by WHO or the World Bank, which may significantly contribute to the increase or decrease of the GDP per capita growth rate. Creating an index of health capital aggregating the most representative (influential) variables for its individual areas can be an interesting alternative to the previously modeled indicators illustrating the health of societies in economic growth models.

\section{BIBLIOGRAPHY}

Arora S., 2001, Health, human productivity, and long-term economic growth, „The Journal of Economic History", vol. 61(3).

Barro R.J., Sala-i-Martin X., 2004, Economic growth, ,Journal of Macroeconomics”, vol. 18.

Bhargava A., Jamison D.T., Lau L.J., Murray C.J., 2001, Modeling the effects of health on economic growth, „Journal of Health Economics”, vol. 20(3). 
Bloom D.E., Canning D., Sevilla J., 2004, The effect of health on economic growth: A production function approach, ,World Development”, vol. 32(1).

Cooray A., 2013, Does health capital have differential effects on economic growth?, „Applied Economics Letters", vol. 20(3).

Domaradzki J, 2013, O skrytości zdrowia. O problemach z konceptualizacja pojęcia zdrowia, „Hygeia Public Heath”, no. 48(4).

Easterly W., Levine R., 1997, Africa's growth tragedy: Policies and ethnic divisions, „The Quarterly Journal of Economics", vol. 112(4).

Fogel R., 2012, Explaining long-term trends in health and longevity, Cambrige Uniwersity Press, Cambridge.

Holland G., 1985, Techniques of health status measurement using a health index, Monographs.

Korporowicz V., 2011, Zdrowie jako kategoria społeczno-ekonomiczna, „Gospodarka Narodowa”, no. 7-8.

Marchewka K., 2000, Główne nurty w teorii kapitalu, „Ruch Prawniczy, Ekonomiczny i Socjologiczny", z. 3.

Morris S., 2012, Ekonomia w ochronie zdrowia, Wolters Kluwer, Warszawa.

Roszkowska S., 2013, Kapital ludzki a wzrost gospodarczy w Polsce, Wydawnictwo Uniwersytetu Łódzkiego, Łódź.

Sachs J.D., Warner A.M., 1997, Sources of slow growth in African economies, „Journal of African Economies", vol. 6(3).

Sygit M., 2017, Zdrowie publiczne, Wolters Kluwer, Warszawa.

Torrance G.W., 1976, Health status index models: A unified mathematical view, „Management Science", vol. 22(9).

Woynarowska B., 2013, Edukacja zdrowotna: podręcznik akademicki..., Wydawnictwo Naukowe PWN, Warszawa.

[www1] Encyklopedia Zarządzania, https://mfiles.pl/pl/index.php/Kapita\%C5\%82 [access 20.05.2019]. 